\title{
Contradictions in Learning to Teach Digital Literacy Practices in an efl Public Setting: An Activity Theory ANALYSIS
}

\author{
CONTRADICCIONES DURANTE LA ENSEÑANZA DE PRÁCTICAS LETRADAS DIGITALES EN ILE \\ EN UNA INSTITUCIÓN PÚBLICA: UN ANÁLISIS DESDE LA TEORÍA DE LA ACTIVIDAD \\ CONTRADICTIONS DANS L'APPRENTISSAGE DES PRATIQUES DE LITTÉRATIE NUMÉRIQUE EN \\ ANGLAIS LANGUE ÉTRANGÈre DANS UNE ÉCOLE PUBLIQUE : UNE ANALYSE BASÉE \\ SUR LA THÉORIE DE L'ACTIVITÉ
}

CONTRADIÇÕES NO ENSINO DE PRÁTICAS LETRADAS DIGITAIS EM INGLÊS LÍNGUA ESTRANGEIRA NUMA ESCOLA PÚBLICA: UMA ANÁLISE DESDE A TEORIA DA ATIVIDADE

Paula Andrea García-Montes Professor, Universidad de Córdoba, Montería, Colombia.

pgarciamontes@correo.unicordoba. edu.co

https://orcid.

org/0000-0003-4443-1091

\section{Juan Sebastián Martínez}

Undergraduate student, Universidad de Córdoba, Montería Colombia. juanxe1998@gmail.com

https://orcid.

org/0000-0002-0021-6085

\section{Andrés Romero}

Undergraduate student, Universidad de Córdoba, Montería Colombia, romerodandresf@gmail.com https://orcid. org/0000-0002-3126-5672

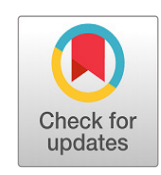

\begin{abstract}
Teaching reforms, methods for teaching EFL and institutional requirements present a significant number of contradictions in the activity system of EFL preservice teachers (PST). As novice practitioners, EFL PST are exposed to these contradictions while engaging in new activity systems, particularly when learning to put theory into practice. Hence, this case study examines the contradictions that an EFL PST, from a university in Córdoba, Colombia, faced when incorporating digital literacy practices (DLP) in her planning as a result of her interaction with the activity theory (АT) elements. It also describes the shifts in agency that occurred when she was exposed to contradictory dynamics of teaching. The study involved the PST and a group of 35 students in 10th grade. Class observations and semi-structured interviews with the PST revealed contradictions in terms of mediating artifacts, objects, division of labor, and rules. They also indicated how the identified contradictions could form the basis for a shift in her teaching activity system. These results suggest teaching programs should not only concentrate on how much our students learn new strategies but also on how much they have acquired transferable skills for transforming their contexts.
\end{abstract}

Keywords: Activity theory; contradictions; digital literacy practices; pre-service teachers; EFL; teacher education.

\section{RESUMEN}

Las reformas en la educación, los métodos de enseñanza del inglés como lengua extranjera (ILE) y los requisitos institucionales presentan un número significativo

Received: 2021-06-10 / Accepted: 2021-09-27 / Published: 2022-02-11

https://doi.org/10.17533/udea.ikala.v27n1a06

Editor: Doris Correa, Universidad de Antioquia, Medellín, Colombia.

Some rights reserved, Universidad de Antioquia, 2022. This is an open access article distributed under the terms of the Creative Commons License BY-NC-SA 4.0 International. 
de contradicciones en el sistema de actividad de los docentes de ILE en formación. Los practicantes están expuestos a estas contradicciones cuando se involucran en nuevos sistemas de actividades, particularmente cuando tratan de poner en práctica la teoría. Así, este estudio examina las contradicciones que enfrentó una profesora de inglés como lengua extranjera al incorporar prácticas letradas digitales (PLD) en su planificación como resultado de su interacción con los elementos de la teoría de la actividad (TA). También describe los cambios en la praxis docente que ocurrieron cuando esta estuvo expuesta a dinámicas contradictorias de enseñanza. El estudio involucró a un estudiante en formación y 35 alumnos de décimo grado. Las observaciones de clase y entrevistas semiestructuradas a la practicante revelaron contradicciones en las herramientas mediadoras, los objetos, la división del trabajo y las reglas. Además, descubrieron cómo las contradicciones identificadas podrían formar la base para un cambio en su sistema de la actividad docente. Los resultados sugieren que los programas de enseñanza no solo deben concentrarse en cuánto aprenden nuestros estudiantes nuevas estrategias, sino también habilidades transferibles para lograr transformar sus contextos.

Palabras claves: teoría de la actividad; contradicciones; prácticas de alfabetización digital; docentes en formación; EFL; formación de docentes.

\section{RÉSUMÉ}

Les réformes pédagogiques, les méthodes d'enseignement de l'anglais et les exigences institutionnelles présentent un nombre important de contradictions dans le système d'activité des enseignants en formation initiale. En tant que praticiens novices, les futurs enseignants sont exposés à ces contradictions tout en s'engageant dans de nouveaux systèmes d'activités, en particulier lorsqu'ils apprennent à mettre la théorie en pratique. Par conséquent, cette étude de cas a examiné les contradictions auxquelles une enseignante d'EFL en formation initiale a été confrontée lors de l'incorporation de pratiques d'alphabétisation numérique (DLP) dans sa planification en raison de son interaction avec les éléments de la théorie de l'activité (TA). Il décrivait également les changements d'agence qui se produisaient lorsqu'elle était exposée à des dynamiques d'enseignement contradictoires. L'étude a impliqué l'enseignant en formation initiale et un groupe de 35 élèves en 10e année. Les observations et les entretiens semi-structurés ont révélé des contradictions en termes d'artefacts médiateurs, d'objets, de division du travail et de règles. Ils ont également indiqué comment les contradictions identifiées pourraient constituer la base d'un changement dans son système d'activités d'enseignement. Ces résultats suggèrent que les programmes d'enseignement ne devraient pas seulement se concentrer sur la façon dont nos élèves apprennent de nouvelles stratégies, mais aussi sur la façon dont ils ont acquis des compétences transférables pour transformer leurs contextes.

Mots-clés : Théorie de l'activité ; contradictions; pratiques de littératie numérique; enseignants en formation initiale; $\mathrm{EFL}$; formation des enseignants.

\section{RESUMO}

As reformas educacionais, os métodos de ensino do inglês e os requisitos institucionais apresentam um número significativo de contradições no sistema de atividade dos professores em formação de inglês como língua estrangeira. Como praticantes novatos, os professores em formação estão expostos a essas contradições enquanto se envolvem em novos sistemas de atividades, especialmente quando aprendem a colocar a teoria em prática. Portanto, este estudo de caso examinou as contradições que uma professora EFL enfrentou ao incorporar práticas de letramento digital (PLD) em seu planejamento como resultado de sua interação com elementos da teoria da atividade (TA). Também descreveram-se as mudanças no desempenho que ocorreram quando ela foi exposta a dinâmicas contraditórias de ensino. 
O estudo envolveu a professora inicial e um grupo de 35 alunos do $10^{\circ}$ ano de ensino médio. As observações e entrevistas semiestruturadas revelaram contradições em termos de artefatos de mediação, objetos, divisão do trabalho e regras de mediação. Estas também indicaram como as contradições identificadas poderiam formar a base para uma mudança em seu sistema de atividade de ensino. Estes resultados sugerem que os programas de ensino não devem se concentrar apenas em quanto os nossos alunos aprendem novas estratégias, mas também em como eles adquirem habilidades transferíveis para transformar seus contextos.

Palavras-chave: Teoria da atividade; contradições; práticas de alfabetização digital; professores em formação; EFL; formação de professores. 


\section{Introduction}

The new digital literacies that learners currently bring to our EFL classes pose pedagogical challenges to pre-service teacher' activity systems. Advances in technology have transformed the ways our students read and write. For instance, some learners are no longer reading and writing through paper-based activities, they prefer a variety of means to access content such as videos, audio books, digital comics, social media, mangas, video games, and so forth (Gee,1996; Bull et al., 2016). These new ways of dealing with written and spoken discourses is a call for current trends in teaching and learning.

In this regard, teacher education programs in Colombia have included approaches and strategies pre-service teachers (PSTs) can use to develop students' digital literacies in their classes like flipped instruction, gamification, blended learning, taskbased learning, and so forth (Díaz \& Rúa, 2016; secondary teachers from Monteria, Colombia use national guidance such as the suggested curriculum and basic learning rights to plan lessons and programs from which most of the suggested activities include reading and writing through digital means such as blogs, websites, videos, and virtual platforms (Colombia MEN, 2016).

However, these reforms and teaching methods present a significant number of contradictions in the activity system of PSTs that are learning to integrate their students' new digital literacies in their EFL classrooms since the majority of novice teachers are usually exposed to new teaching systems. Most of the teaching experiences PSTs bring to their classes are based on the examples they have observed from their teachers and theory they shared in their pedagogical practicum classes. However, the theory-practice gap is still present in PSTs teaching practicum as students face many challenges and tensions when putting new approaches into practice (Furman et al., 2019). Hence, the teacher learning process should be coined with the analysis of the contradictions

that emerge within and among activity systems as sources of information for transforming teaching processes (Tsui \& Wong, 2010).

Studies on ongoing training for in-service and PSTs have reported positive results in the development of students' new literacies (Cherner \& Curry, 2019; Maher, 2020; Carroll, 2011; Milton, 2013; Wray \& Medwell, 2000). Results have shown strategies PSTs can develop to bring media literacy skills into their class and content areas.

Research in this field has also revealed the need teachers have to equip students with online reading and writing comprehension through rich, varied, and authentic literacy means. However, to our knowledge, very few studies have delved into the contradictions PSTs faced when engaging in new activity systems such as incorporating digital literacy practices in public schools in Colombia. The only study found in Colombian literature analyzing contradictions in teachers' praxis using $\mathrm{AT}$ is by Sagre et al. (2021). The authors studied the contradictions two English teachers faced when using genre pedagogy for teaching reading and writing in their public contexts. Results revealed transformations in teachers' praxis by adopting a new approach. The study also showed contradictions in grammar teaching that resulted from the teachers' exposure to the new activity systems.

Internationally, a few studies (Stouraitis et al., 2015; Park \& De Costa, 2015; Said et al., 2014; Ares \& Peercy, 2003) have suggested that crossing boundaries is a difficult task for teachers when being exposed to new teaching ways which constrain their teaching activity in different areas. Research has also demonstrated the impact of $\mathrm{AT}$ as an analytical tool for recognizing individual, social, and contextual issues that interfere positively or negatively in teachers' learning and teaching practices (Sannino et al., 2009; Barahona, 2015).

Given this gap, this study examined the contradictions that a PST (pseudonym Juliana) experienced 
when learning to teach with digital literacy practices in a public school in Monteria, Colombia. The specific research question addressed by the study was the following: What contradictions does a PST experience when learning to teach Digital literacy practices in a public school in Colombia? Contradictions in this study refer to conflicts that have been accumulated historically which have shaped not only one element of the activity of a teacher but the whole system (Engeström, 2001; Potari, 2013). The forthcoming chapters will unveil the contradictions we identified in the PST and how some of these conflicts turned into learning opportunities.

\section{Theoretical Framework}

This study draws on activity theory and digital literacy theories. As such, the following paragraphs describe key concepts within these theories such as activity theory, contradictions, and new digital literacy practices.

\section{Activity Theory}

Activity theory traces its history on the works of Vygostky and Leontiév from their studies of cultural-historical psychology in the 90s and developed later by Engeström (1999) with studies about mediation by considering community as an element in the activity system. AT is a conceptual and analytical framework based on the premise that activity is primary and that action precedes thinking. It proposes "that goals, images, cognitive models, intentions, and abstract notions like definition and determinant grow out of people doing things (Morf \& Weber, 2000, p. 81). Thus, in $\mathrm{AT}$, human activity is never separated from cultural artifacts. People cannot understand social interaction without cultural representations or means, and "...society could no longer be understood without the agency of individuals who use and produce artefacts" (Engeström, 2001, p. 134). Furthermore, AT uses the elements of the system as a unit of analysis. The activity is divided into the analytical components, for instance, subject,
Figure 1 Activity Theory Model (Engeström, 2001)

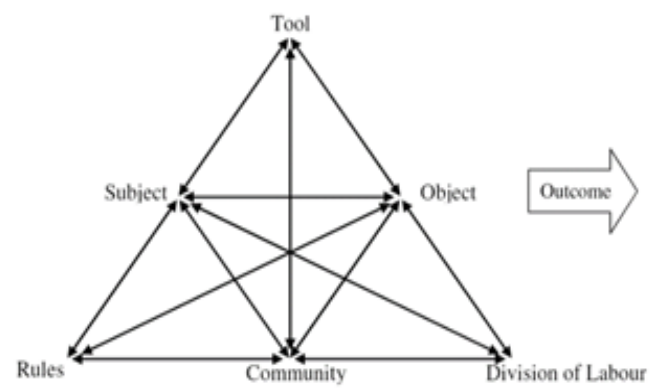

object, division of labor, community, rules, and mediation tools. In this system, the subject is the person or participant being analyzed. While the object refers to the intended activity or objective the subject has in his or her activity. The mediation tools are the devices by which the actions are executed (for example, signs, language, machines, and computers; Hasan \& Kazlauskas, 2014), whereas rules refer to the main conditions that provide information regarding the way people may act as a result of social conditions. Division of labor deals with how actions, and operations are distributed among the participants enrolled in the activity system. These two last elements constitute the modifications Engestrom made to Vygostky's original theory. Community on the other hand, refers to society or groups involved in the activity. Figure 1 illustrates the elements of AT.

The top side of the triangle refers to the activity at the individual level, which Engeström called "the tip of the iceberg." The opposite of the top triangle is acknowledged as the variety of actions "embedded in a collective activity system" (Engeström, 2001, p. 134). This triangular model also consists of two overlapping triangles: the external, located in the outer triangle and the internal, seen in the inner triangle. The external triangle contains the elements of the mediating tools, rules, and division of labor, whereas the internal one encloses subject, object and community. These triangles also represent a mutual relation among the elements from the internal and external in the triangular model. For instance, the interrelated relationship between 
the internal and external system can be explained as follows: the relationship between subject and object is mediated by the artifacts, the relationship between subjects and community is mediated by rules, and the relationship between the object and community is mediated by division of labor.

Engeström explains that the activity system integrates all these elements since they offer a holistic method of analysis and understanding of human interaction with the components of the system. Hence, AT constitutes a valuable tool for researchers to underpin the complexity of human activity on the interaction between people and their mediating artifacts which have been transformed by humans and their activity. It is also geared towards a research practice that describes from different lens teaching processes and products.

\section{Contradictions}

Contradictions are key aspects in the analysis of AT elements. They are known as tensions or conflicts within the elements of the activity systems. Contradictions are defined as historically accumulating tensions within the activity systems in which the person has engaged. (Engeström, 1999). This indicates that contradictions are not only problems; they are rather conflicts that have been accumulated historically and which have shaped not only one element of the activity but the whole system. Contradictions also indicate the dialectic misfit within the elements of the AT. In this regard, contradictions constitute the force that causes change in the activity system. Thus, contradictions identified in the activity system of a person may create learning opportunities for the subject, offering wider options of possibilities for change (Engeström, 2001; Potari, 2013). When these contradictions are collectively analyzed and identified, subjects become aware participants and may decide on possible transformations of their activity system turning all these disturbances into learning opportunities (Engeström, 1999). Hence, contradictions that lead to change required "a socially contextualized intellectual resolution”
(Smagorinsky et al., 2004, p. 22). Despite the potential of contradictions to change and transform the activity system, they do not always result in successful transformations. Therefore, contradictions can enable change or disable it since it depends on whether the contradictions were identified, acknowledged, and resolved (Nelson, 2002).

The inner contradictions come in four types. Primary contradictions are within each element of the activity system. Secondary ones are found between the constituents; while tertiary contradictions juxtapose the "object of the dominant activity with the object of a culturally more advanced activity," and the quaternary contradictions exist between each "entity of the dominant activity and the neighboring ones" (Engeström, 1987; Roth et al., 2004. p. 179). In this study, we looked at the contradictions that took place in a PST when developing students' digital literacy practices when planning, designing, and incorporating technology in each lesson at a public school.

\section{New Digital Literacy Practices}

Digital literacies have gained a remarkable relevance in the past few years given the increase of digital technologies and its uses in different domains of life. Nowadays, reading and writing are used not only for academic purposes but also to generate social interaction with the aid of digital technologies. Hence, Bullock (2016) noted that "digitally mediated reading and writing practices are mobilized to construct knowledge, social relationships, and identities" (p. 18). Digital literacy is a holistic concept that embraces much more than the use of digital tools and the abilities that students should develop to survive in this digital society. It is more related to students' capacity to thrive in their academic, personal, employment and social lives. Literacy practices in digital spaces are often known as new literacies that students should develop, which are different from those we use in print-based literacies (Coiro et al., 2008).

The new literacies that students have engaged in these days are characterized by its components 
of collaboration, participation, distribution, and nonlinear process as well as multimodality and creativity (Coiro et al., 2008; Lankshear, \& Knobel, 2011). In addition, digital literacies are also culturally and socially situated. For instance, people engage with a variety of tools in very particular ways in their daily lives. Thus, people do not always conceive, use, interpret, and accept digital tools as what they were originally designed for (Tour, 2012); rather they use them for different purposes and practices.

\section{Method}

The study follows a qualitative design in order to describe the phenomenon, give insights, and understand it rather than proving or testing an issue (Duff, 2008). Specifically, it uses a case study approach to explore the contradictions in a PST teaching system when developing students' DLP. According to Robson (2009) a case study is used when a phenomenon or event is to be studied in detail at its natural settings from different perspectives. Accordingly, this case study involves a detailed investigation of the phenomenon and its setting by using a variety of data collection procedures intended to unveil the contradictions a PST faced when incorporating DLP in her class and shifts in her teaching agency.

\section{Participants}

The participants of the study were a PST (pseudonym Juliana) and a group of 35 students from $10^{\text {th }}$ grade. At the time of the study, the teacher was a student at the EFL teacher preparation program at Universidad de Cordoba, Colombia. She was doing her teaching practicum II at a public school and was conducting her research project on the use of flipped learning to develop students' DLP in the same setting. As she was enrolled in research courses, she participated in workshops about the teaching of literacy and digital literacy practice. Her research advisor held frequent conversations with her and guided her with lesson plans, reflections, and activities. She also revised Julianas' planning and created strategies to help her transfer theory she studied in her teaching practicum course to her daily teaching at school. Juliana was not acquainted with the activity system until she revised the AT elements with her. The authors of this paper played the role of researchers. We observed lessons, prepared the narratives, transcribed information, planned sessions, and discussed contradictions with Juliana.

\section{Data Collection}

This case study employed methods such as three semi-structured interviews, five observations along with five ethnographic narratives to answer the question of this research. Ethnographic narratives from the observations were written down by two researchers in order to produce a more complete picture of Juliana and her students' interactions during the class (Nunan \& Bailey, 2009). In addition, ethnographic narratives served to understand the PST's activity system and described how Juliana and her students engaged in activities to develop their digital literacy practices with mediating artifacts.

Three semi-structured interviews were applied to Juliana at the beginning, during, and at the end of the project by one of the researchers. These interviews helped to unveil contradictions among the elements of the PST's activity system. All the procedures applied in this study with human participants were done so with informed consent, signed by the main participant. The study was also approved by Juliana's teaching practicum coordinator.

\section{Data Analysis}

For the analysis of the PST's contradictions, activity theory was used (Engeström, 1999). The elements specified in the triangles of the AT framework were used as codes for unveiling details about the tensions in the elements of the PST's activity system. All codes were processed in excel through a qualitative analysis that facilitated the comprehension of the elements in the teacher's practice. 
Thematic analysis helped (Braun \& Clarke, 2006) to categorize the data gathered by analyzing elements such as: subject, object, tools, division of labor, community, and rules. In addition, these elements were carefully discussed with the PST at the starting point of this research as well as during her teaching process and at the end of her teaching practicum. This was done to make the PST (Juliana) aware of the elements with which she would interact in the new teaching experience in order to identify contradictions or tensions. The interviews we carried out were transcribed and categorized to aid in identifying contradictions expressed by the PST (Juliana). The categories that revealed Juliana's contradiction were obtained from her interaction with three elements, rules, object, community, and division of labor.

\section{Lessons and Mentoring}

The lessons designed by Juliana involved digital means to develop students' literacy skills. The teachers found a need for engaging students in new ways of reading and writing in her class since traditional paper-based activities were not meaningful for students, who reacted negatively any time paper reading materials were taken to class. Thus, five lessons were designed by the PST and a mentor who reoriented the teaching cycle the PST used for practicum one.

The PST's initial planning addressed mostly grammar and vocabulary activities at the beginning of the lessons, particularly from the warmup to the preparation stage. The mentor helped turn this format into a more sociocultural view of planning, leading the teacher to use texts as the center of instruction. In this sense, the teacher used written and oral texts like opinions from blogs students like reading outside their classes, from anecdotes telling stories of past events found in websites, and from videos. This allowed the PST to initiate the lesson with a written or oral text, for example, to talk about its context, culture, and social purpose. Then, she explained the text to students by modeling the language demands for the task and emphasizing on meaning and form if required. After that, students performed tasks like talking about healthy food, routines, vacation, and sports, for example, as Juliana modeled the main task during the preparation and practice stages of her class. Figure 2 shows Juliana's activity system before enrolling in incorporating new digital literacy practices in her practicum II course.

The red arrows point at some elements from Juliana's initial teaching that needed to be modified to engage in the new activity system (teaching new digital literacies). For instance, the object of her class suggested the teaching of grammar and vocabulary, following strict plans from the suggested curriculum. It also showed the need to motivate students to read and write in the English lesson. However, she recognized students needed more hints and support to align with reading and writing activities. When discussing with her advisor, she identified missing stages in her teaching process like modeling strategies, teaching for communication, and teaching from the text. This analysis helped Juliana to become more conscious of new elements she needed to shape and add to her teaching in order to achieve the object of her class. For instance, the PST had to modify the object of her class by planning lessons that involved more active and interactive roles from students to achieve communicative goals.

As seen above, the mediation tools initially used suggested mostly paper-based activities and a mismatch between the community interests and the mediation tools chosen. As explained by Juliana in the diagram, students seemed to dislike reading and writing through paper-based activities, which meant a lot for her new planning experience. Rules from the institution required Juliana to use books and national guidance for planning and accomplishing her personal teaching goal and that one required from the institution. In addition, her main objective was to teach the topics students needed to learn at their school level, 
Figure 2 Juliana’s Initial Activity System

\section{MEDIATION TOOLS}

Teacher explanations, worksheets, videos, book, reading activities with questions and games. Some online activities for vocabulary practice and paper based materials for reading and writing

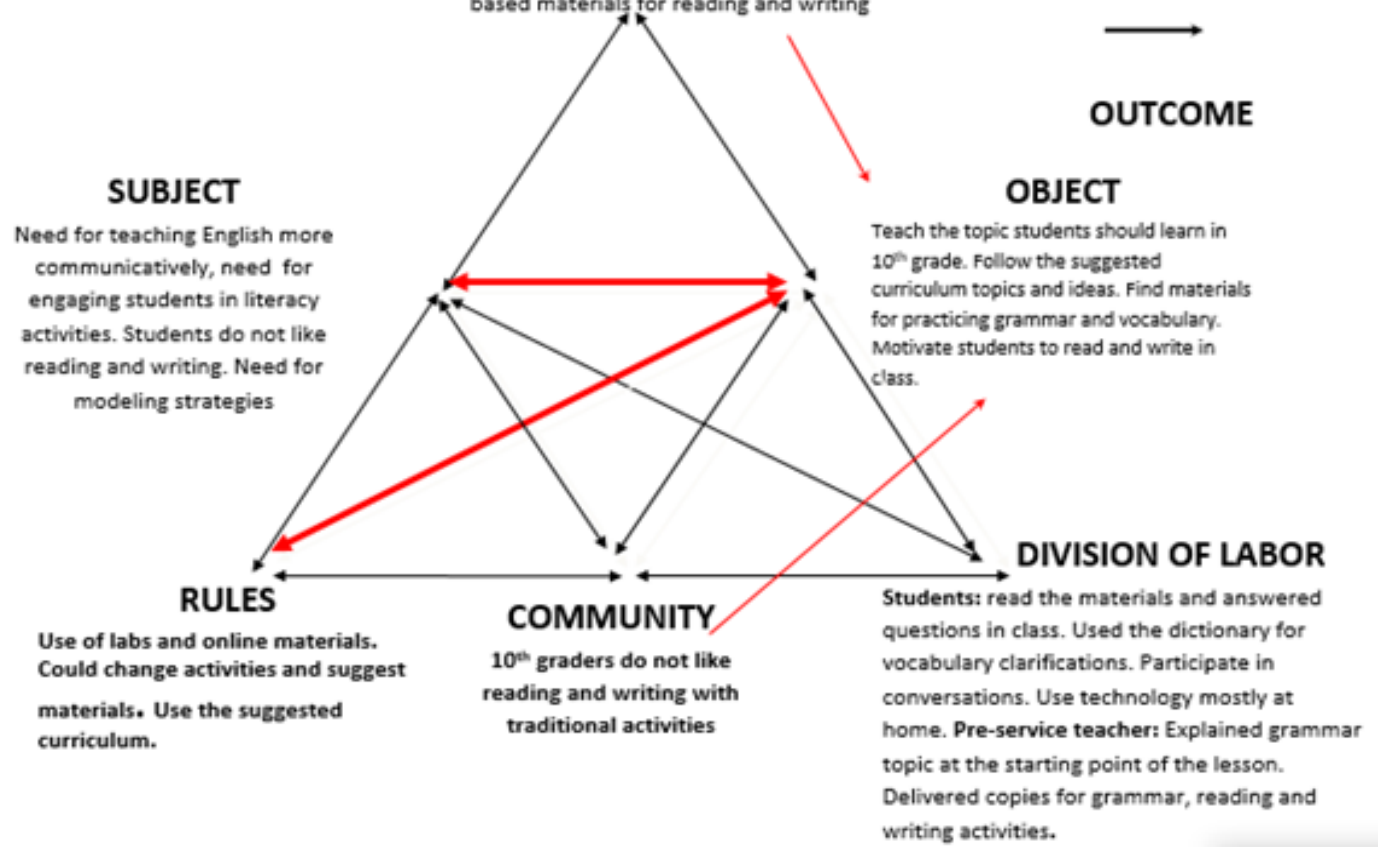

teach grammar and vocabulary, and follow the national and institutional guidance for planning.

This initial analysis was discussed with Juliana to identify contradictions and make the needed changes for the new teaching experience described in the results of this article. For example, she needed to motivate students to read and write in her classes by integrating the ways students read and write outside of the school. She identified the need for selecting oral or written texts students could study to learn content and English instead of aligning suggested curriculum topics with those that are found on the web.

When analyzing her teaching cycle, it seemed she went from presenting grammar and vocabulary exercises to students performing writing and oral activities without providing them with substantial support and modeling to build oral or written texts.

\section{Findings}

Findings from this study include contradictions among some activity elements such as mediating artifacts, rules and subject, and contradictions between the community (students) and division of labor (students and teacher's roles). In addition, they include shifts in Juliana's teaching of DLP.

\section{Contradictions Among Mediating Artifacts, Rules, and Subject when Incorporating DLP in EFL Lessons}

The first contradiction identified in the PST was aligning topics with technological tools. The educational system and requirements for teaching at the school where Juliana did her practicum are associated with two teaching guidelines called the suggested curriculum and basic learning rights that PSTs and in-service teachers should use for planning. These guidelines represented a conflicting 
element of the teaching-learning activity in Juliana's practice. Thus, some difficulties were presented, for instance, when deciding which digital tools might serve the most for the topics provided by the syllabus and suggested curriculum, as stated by Juliana during her interview:

\section{Excerpt 1}

So, before I begin my classes, I try to make sure that the topic I will work with can be conveyed by means of technology. I try to plan very well and choose according to the topics we are studying. The easiest part is to find something that goes according to students' circumstances and think of what to do, for example: I will take a video, but then comes the challenge; what video to choose. (PST interview)

In these excerpts, contradictions between the tools and rules were causing tensions in Juliana's planning and decision making in terms of digital materials for her classes. She found it very challenging to locate texts that matched grammar and vocabulary aspects specified in the institutional documents and guidance for teaching in the school.

The second contradiction found was adapting and selecting materials to meet students' English level. Juliana refers to this tension in the interview as follows:

\section{Excerpt 2}

Something that is simple in terms of language for students to understand meaning, and a video that aligns with what I will teach is required so that students can follow the model I showed for them as guidance for the final product (PST interview).

Contradictions between DLP tools and subjects (students) also traced the inner difficulties Juliana faced in response to the new system she engaged in. This tension was influenced by the curricular requirements in the school and her interaction with students in the classroom.

The third contradiction was evident when asking Juliana about arrangements in the institution for using technology to develop students' digital literacy practices. Tensions regarding rules and the relationship of the community with digital tools posed conflicts in the use of technology in her classes.
Teachers should first make the needed arrangements for using technology (e.g., find out whether technological tools were available or not, monitoring devices, checking internet access, availability, and so forth). Juliana stated the following:

\section{Excerpt 3}

Technology in the classroom was not fully available; I always had to go to the library to ask, for example, Is the lab available day? For example, the internet from the school sometimes did not work, so you should download the video beforehand. I never trusted even though I had access to all the materials from the school. I took with me an USB to use the video; it was easy this way. (PST interview)

Excerpt 3 shows how Juliana transforms this difficulty into a learning opportunity by becoming more resourceful and locating a second plan for encompassing new possibilities to integrate DLP in her English lesson. In the background of this contradiction is Juliana's tendency of planning and thinking of possible constraints she might face in her classes. She continued her explanation by illustrating a case she experienced:

\section{Excerpt 4 \\ On this occasion, I scheduled the room, but when I ar- rived at school I was told that a teacher needed it, no it can be possible! (Juliana exclaimed), my class is today and is all mediated with technology. If I do not use tech- nology, I cannot teach this class! (She exclaimed). What can I do?. So I had to improvise and went to look for a video beam and speakers. Thus, we need to always have a plan $b$. If the lab or technology room does not work, a video beam can work to watch the video in class.}

These constraints facilitated ways to transform Juliana's decision making concerning possible problems technology posed in this particular class. This situation did not intervene much in her creativity within lessons. However, this disturbed her initial plan intended to meet students' technological needs and wants for learning in the English class.

\section{Contradictions Between Two Activity Theory Elements: Community and Division of Labor}

Juliana's contradictions with the division of labor and rules were keeping students interested and 
focused on the activity. Students only executed tasks because technology was integrated for the first time in their English classes. Thus, their excitement to use technology without any academic value posed contradictions between Juliana and students' attitudes towards technology, as explained in the following excerpts from the interview:

\section{Excerpt 5 \\ When the class is very interesting, one can devote some time to it. We may say: In this activity all the students participated and conducted the activities willingly. Once in a while, some activities in the class- room can take longer. So, they wanted me to play another video. But even when I said no, they insisted to watch a movie, and that was the only thing they wanted to do (PST interview). \\ Excerpt 6 \\ Well, sometimes they think that if I [the pre-service teacher] am bringing some technological device to the class, then, it is just that. Hey, we're going to... relax, since we are just watching videos. If I ask them to watch the movie to do some activity related to it later on, they use to complain: Nooo, teacher! They only want to watch the movie, and that's all. (Pre-service teacher interview)}

This breakdown in terms of rules and students' attitudes narrowed Juliana's objective of supporting students' English learning. As seen, students did not want to do any academic tasks; instead, they preferred movie time and entertainment. However, it was solved by using persuasion and adding academic values to videos, movies, and online material used in the English class.

\section{Shifts in Juliana's Teaching of DLP}

Some of the identified contradictions could form the basis for a shift to Juliana's teaching activity of DLP. When asked about possible shifts in her professional development and knowledge as a teacher, Juliana reported in the interview that this experience had a substantial impact on her ability to create student-centered activities and incorporate DLP in her classes. In excerpts 7 to 9, Juliana revealed some gains:

\section{Excerpt 7}

For example, I used to think that if I did not give the students vocabulary or grammar from the beginning of the class, then they were not going to perform in the same way.

\section{Excerpt 8}

I planned to teach meaning, to teach something communicatively which is something different. I put them to fill, to complete, to fill-in-the-blank, those things like that. They kind of do it in a moment but they don't see the meaning (...). So with technology it seems different to me and I have had good results.

\section{Excerpt 9}

You show them a blog with an opinion, and they can be asked what they think of that opinion. For example, the students interact more because it is something more productive, something that they are always familiar with (...).

According to Juliana, she gained many insights from the emerging contradictions such as teaching with a communicative goal and using technology for designing goal-oriented tasks that focused on students' active roles in lessons. This result was enhanced by her constant interaction with her advisor who supported her with teaching principles and strategies to achieve her purpose of her pedagogical practicum. The transcription in Figure 3 showed how she responded to the challenge she was posed by the advisor to meet her teaching needs.

As seen above, she expanded her teaching experience and brought important considerations such as incorporating students' DLP that they usually found outside public schools due to lack of technological resources. She found that multimodal texts and digital tools promoted more learning opportunities to students and kept them focused during the class. However, she did not consider the teaching of grammar and vocabulary unnecessary for students. Instead, she placed grammar and vocabulary exercises later in the lesson (Figure 4).

She continued explaining about her teaching practice transformation and gains in students' 
Figure 3 Interaction Between the Pre-service Teacher and the Advisor

\begin{tabular}{|l|}
\hline Tutor \\
What was it like to put the theory we studied into the classroom? How did the switch \\
(teaching communicatively and with texts and technology) go from not using \\
technology to using it? \\
It causes them more curiosity; it always causes them more expectation of "what is he \\
going to show us?" or "what he is going to do". It keeps them entertained in that \\
aspect; and for example, in my case, every time they saw me arrive, they said, \\
"Teacher, let's go to the living room;" "Today we are going to watch a video?" So they \\
are always waiting for me since they noticed their classes are changing. \\
Well, if it's vocabulary, you can't ask them what they think. On the other hand, when \\
you show them a blog with an opinion, you can ask what you think of that opinion. For \\
example, the students interact more because it is already something more \\
productive, something that they are always related to. In the end, they also had to \\
use technology because they were going to do something similar to a blog and an \\
email in a document.
\end{tabular}

learning; for example, she gained awarenes about the importance of teaching meaning, context, and culture since she noticed changes in her students' motivation and interest about learning English. Her students became active participants in the classroom by responding to questions, creating presentations, reading blogs, and exploring different oral and written texts. Below is Juliana's recount of her improvements. In Excerpt 10, Juliana highlighted some of the changes we perceived when transforming her teaching system:

Excerpt 10

But the shift from planning to teaching meaning, to teaching something communicative is completely different. As

Figure 4 A Shift in Juliana's Teaching of Grammar and Vocabulary

\begin{tabular}{|c|c|}
\hline \multirow[t]{4}{*}{ Tutor: } & What I conclude is that you think that when you \\
\hline & use technology in one way or another, you are \\
\hline & leaving behind that theory: without vocabulary, \\
\hline & my students are not going to learn. \\
\hline Julian & $\begin{array}{l}\text { When you use technology in one way or } \\
\text { another, you are leaving behind that theory that } \\
\text { if vocabulary is not taught at the beginning of } \\
\text { the lesson, my students are not going to learn. } \\
\text { However, for the production stage of the lesson }\end{array}$ \\
\hline & $\begin{array}{l}\text { they should know any vocabulary and } \\
\text { structure. If you have your activities well } \\
\text { planned, everything happens. }\end{array}$ \\
\hline
\end{tabular}

a teacher, you have better benefits and better results, you feel that your practice really works. So, I have seen that my students this semester have performed very well: They have all participated, they have all worked. Something curious is that they remember topics, functions of the language, rather than isolated vocabulary or things like that, but (...) Yes, technology, I think it has also helped them to develop their learning. (Interview with the pre-service teacher).

This transformation was also evident when Juliana interacted with students. We noticed her class initiated by presenting content rather than lists of patterns and vocabulary activities isolated from context and content (see Table 1).

This shift took place after obtaining positive results with DLP. Although students were not proficient with the language, they interacted with the pre-service teacher in English using single words. As shown in Turns 1, 3, 5, and 7 the teacher gave some examples of the activities she liked doing and asked questions to promote teacher-student interaction. Questions were very important for the lesson since the teacher could use pictures and texts in the power-point with two main purposes: promoting interaction and presenting the topic of discussion (free time activities). Real pictures kept students interested during the lesson and corroborated Julianna's comments regarding students' motivation when digital resources were used in their English class. 
Table 1 Talking about Free-Time Activities (excerpts)

\begin{tabular}{lll}
\hline Turns & Participant & \multicolumn{1}{c}{ Excerpts of their interactions } \\
\hline 1 & T & Hey so, that's the topic for today ::: spending time well and giving recommendations ::: eh l'm going to tell you the \\
way I spend my time well. It means for vacations, free time, holidays::: eh, so let's see, for example we can do many \\
activities like going to the beach::: eh mountain bike ... or riding a bike, listening to music, so l'm going to tell you \\
the way I spend my time::: 0 ok, so, eh I like going to the beach, do you like going to the beach? \\
\end{tabular}

Juliana's reconceptualization of her practice revealed gains in terms of teaching meaning rather than form; however, it seems to be a challenge and a call for further teaching and more understanding of possible gains as she stated in the following comments:

\section{Excerpt 11}

I think my students are used to old English teaching. This is more dynamic (teaching with technology), but students seemed not to find it necessary to write, learn explicit grammar and vocabulary, and in the end, it is disappointing for me because I feel that I am not doing things well, but then I think it is that they are suddenly used to another way, it is confusing.

This shift in her activity system with the new challenge of incorporating DLP in EFL classes also provoked innovative opportunities for using technology inside and outside the classroom for academic purposes.

\section{Excerpt 12}

Yes, we are in $21^{\text {st }}$ century skills and they are very familiar with technology. Sometimes we have used WhatsApp to do class work. So, I tell them like, ok guys send me that on WhatsApp, and for them it is something easy, and it is something new for them to have in class; but it is something they know how to use.

This was an identified contradiction that was shaped by adopting and adapting a variety of tools that students could use with a learning goal. This resulted in new ways of supporting student learning. This pre-service teacher had the opportunity to bring her contradictions in their practice to the leading edge and to determine how she would address conflicting situations to succeed in her lessons.

In the transcript in Table 2, Juliana did not have access to the lab to work on their digital literacy practices with her students. To solve this constraint, she went to the usual classroom with a data projector and a video about daily activities she had downloaded previously. Students watched a video about daily activities and answered some questions related to time.

In Turns 1, 3, 4, 8, and 10, the pre-service teacher used questions such as "What does she do in the afternoon?" and "At what time does (...) Ariadna* have dinner?" in order to promote class interaction and strengthen their listening skills. In the lesson, many DLP were used such as videos, blogs, audios, and pictures in order to teach specific content and help students develop communication skills. This tension enriched her capacity to transform negative situations that she faced into learning opportunities.

Figure 5 summarized the contradictions found in Juliana's activity. In comparison to the initial activity system, we could identify the pre-service 
Table 2 Transcript: Interaction from the Video about Daily Routines

\begin{tabular}{lll}
\hline Turns & Participant & \multicolumn{1}{c}{ Excerpts from their interactions } \\
\hline 1 & T & Hey, what does she do in the afternoon? \\
2 & S? & Watch TV \\
3 & T & Watch TV (..) she is paying attention (.) to what? She is paying attention, she is listening \\
4 & T & Guys, at what time does (..) Ariadna* have dinner? At what time? Dinner? \\
5 & S? & Six fourteen \\
6 & S? & Eight o'clock \\
7 & S? & Seven o'clock \\
8 & T & Where is Ariadna*? What time Adriana? \\
9 & S1 & Six fourteen \\
10 & T & At six fourteen, who said six fourteen? \\
11 & SS & ((separately, but sequentially, they were saying, "Yo" = "Me")) \\
\hline
\end{tabular}

teacher could cross boundaries and learnt from her interaction with the elements of this new teaching experience. The red arrows in Figure 5 showed the contradictions the PST went through during her teaching experience.
Juliana's new AT evidenced changes in her repertoire as a novice teacher. She modified initial ideas concerning the subjects of her class since she found two main needs in students' learning: (a) They required more opportunities to explore

Figure 5 Contradictions in Juliana’s Activity System

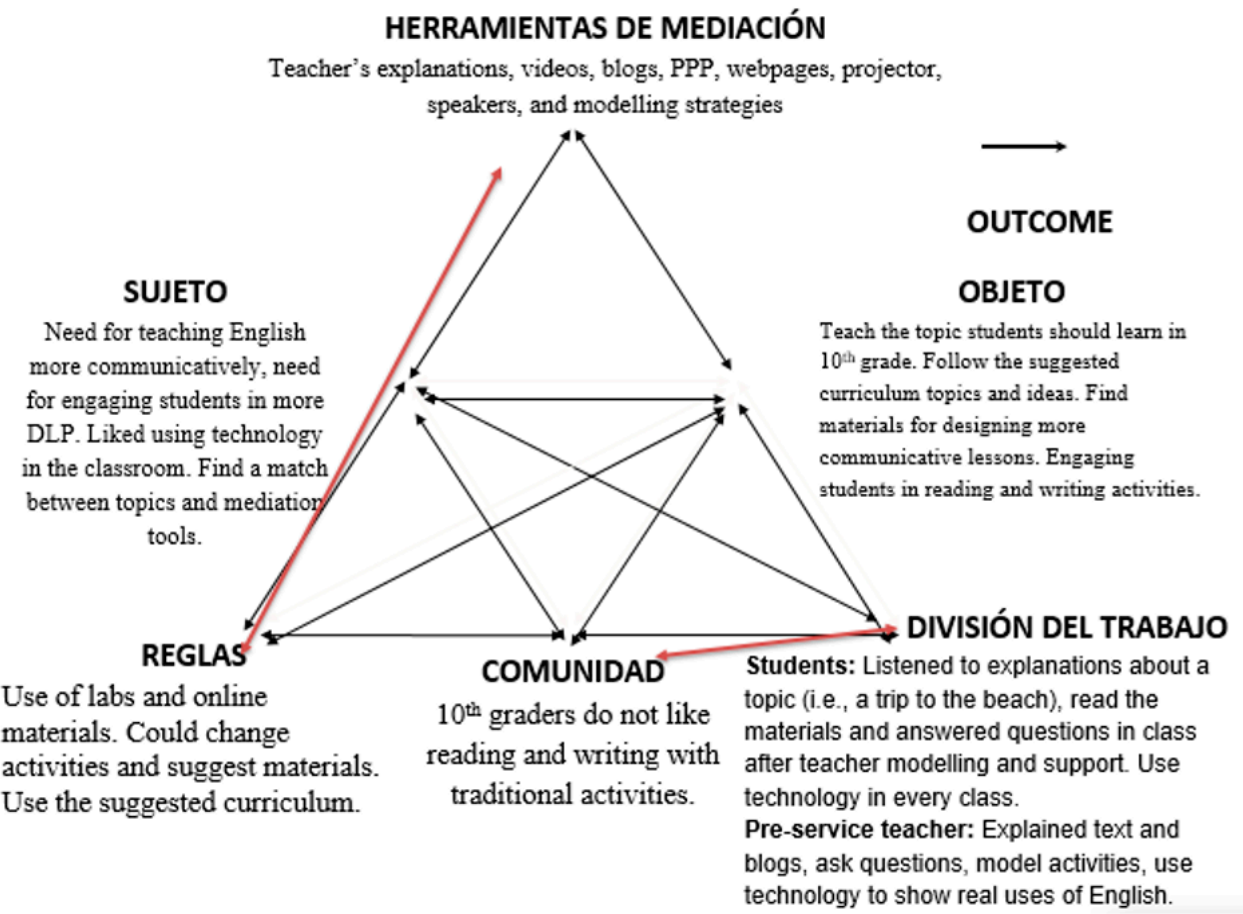


their outside DLP within the English class, and (b) students needed to communicate ideas in the classroom. These allowed her and the advisor to think of strategies to afford these opportunities to students. In terms of rules, she could transform many negative constraints into learning opportunities such as the arrangements to use the lab and the alignment of topics with the suggested curriculum. However, institutional requirements will pose more constraints due to lack of resources from this public school.

At the beginning of the project, her community was demotivated for the class and showed lack of interest in reading and writing. After modifying some elements such as mediation tools, object of her class, and division of labor, we considered there were significant transformations since we could observe students interacting, exploring new digital tools for learning English, and engaging in opportunities to read and write using mediation.

The red arrows still point at some contradictions that Juliana should keep solving as rules, division of labor, and selection of mediation artifacts during her lessons. We observed tensions between the object of her classes (communication activities and literacy) and the selection of mediation tools. For instance, selecting authentic materials like audios, texts, and videos that matched with the suggested curriculum syllabus is a challenge for Juliana due to the mismatch that exists between topics suggested and students' English level. These arrows also point to some tensions regarding students' misinterpretation of uses of technology that still cause troubles in students' behavior and lesson goals achievement.

However, this diagram also shows some of the gains during the interaction with the elements of her new activity system. For instance, Juliana seemed to have modified the object of her class. At the initial stage of this study, she was attached to the idea that without explicit grammar and vocabulary at the beginning of the lesson students were not capable of producing oral and written texts.
Her thoughts were transformed by adding more content and culture at the starting point of the lesson. Now, she is more concerned about including communicative tasks and activities mediated with technology in order to incorporate students' DLP. We also noticed that dialogues held with her advisor served to add other strategies like modeling and technology. For instance, modeling strategies served to demonstrate how language was used in context and for the product of the lesson to students. In addition, division of labor seemed to have motivated students' participation in topics. This element was relevant for her new activity system since she varied students' roles. For example, students went from using paper reading activities and answering questions to creating multimodal presentations, videos, blogs, e-mails to describe their routines, free time activities, and state opinions.

As seen above, the mediation tools were shaped from paper based to more authentic and digital means allowing more real approximation for what students used to read and write outside their classes. Table 3 compared Juliana's initial and improved areas of her activity system.

\section{Discussion and Conclusions}

This study reports Juliana's contradictions in her teaching system when developing students' DLP. These contradictions were in terms of the following activity theory elements: artifacts, community, division of labor, object, and tensions with some rules from the institution. In the face of these contradictions, her beliefs, and previous knowledge of teaching were interrupted by a variety of forces that increased her ability for coping with dilemmas and contradictions. These findings resonate with Said et al.'s (2013) notion that knowledge can be constructed as "results of interaction and negotiation of conflicting and different understanding of circumstances teachers daily face in their classrooms" (p. 14).

These contradictions made it inevitable for the transition in Juliana's teaching to occur. They also 
Table 3 Analysis of Juliana’s Shift and Contradictions

\begin{tabular}{|c|c|c|c|}
\hline $\begin{array}{l}\text { AT } \\
\text { elements }\end{array}$ & Initial Activity System & Contradictions & $\begin{array}{l}\text { Improved Areas (Learning } \\
\text { Opportunities) }\end{array}$ \\
\hline $\begin{array}{l}\text { Mediating } \\
\text { Tools }\end{array}$ & $\begin{array}{l}\text { Only paper-based activities, } \\
\text { worksheets, teacher's explanations, } \\
\text { vocabulary activities, videos }\end{array}$ & $\begin{array}{l}\text { Contradictions between the tools and rules } \\
\text { caused tensions in Juliana's planning of } \\
\text { digital materials for her classes and tensions } \\
\text { regarding students' misinterpretation of uses } \\
\text { of technology. } \\
\text { She found it very challenging to locate texts } \\
\text { that matched grammar and vocabulary aspects. }\end{array}$ & $\begin{array}{l}\text { Variety of digital texts in web pages, blogs, } \\
\text { videos, and modelling strategies. } \\
\text { She became more resourceful and usually } \\
\text { found a second plan for integrating DLP in her } \\
\text { English lesson. }\end{array}$ \\
\hline Subject & $\begin{array}{l}\text { English teacher interested in } \\
\text { motivating students to like reading } \\
\text { and writing. Tired of teaching } \\
\text { without results, she found a need } \\
\text { to teach more communicative } \\
\text { classes. }\end{array}$ & $\begin{array}{l}\text { Need to teach English communicatively. Need to } \\
\text { engage students in literacy practices. }\end{array}$ & $\begin{array}{l}\text { Variety of modeling strategies for students } \\
\text { to perform reading and writing tasks } \\
\text { independently. Advisors' support permitted } \\
\text { the inclusion of these modeling tools and } \\
\text { promoted reflections. } \\
\text { Juliana admitted that students seemed to be } \\
\text { more committed to the incorporation of DLP. }\end{array}$ \\
\hline Object & $\begin{array}{l}\text { Teach the topics students should } \\
\text { learn in } 10^{\text {th }} \text { grade. Follow the } \\
\text { suggested curriculum topics. Find } \\
\text { materials to practice grammar and } \\
\text { vocabulary. Motivate students to } \\
\text { read and write in class. }\end{array}$ & $\begin{array}{l}\text { "Yes, for example, before I thought if I did not } \\
\text { provide students with vocabulary or grammar } \\
\text { from the starting point of the lesson, they } \\
\text { would not succeed in the lesson." } \\
\text { Juliana struggled when selecting authentic } \\
\text { materials that matched with the suggested } \\
\text { curriculum syllabus. Juliana found a mismatch } \\
\text { between topics suggested and students' English } \\
\text { level. }\end{array}$ & $\begin{array}{l}\text { Teach the topic students should learn in } \\
10^{\text {th }} \text { grade. Follow the suggested curriculum } \\
\text { topics. Locate materials or design more } \\
\text { communicative lessons, engaging students in } \\
\text { reading and writing activities. } \\
\text { She integrated more communicative goals } \\
\text { and technology for designing goal-oriented } \\
\text { tasks that focused on students' active roles } \\
\text { in lessons. }\end{array}$ \\
\hline $\begin{array}{l}\text { Division of } \\
\text { Labor and } \\
\text { Community }\end{array}$ & $\begin{array}{l}\text { Students read materials and } \\
\text { answer teacher's questions. Used } \\
\text { the dictionary, participated in } \\
\text { conversations, and used technology } \\
\text { at home. } \\
\text { Juliana explained grammar at } \\
\text { the beginning of the lesson and } \\
\text { delivered copies of grammar, } \\
\text { writing, and reading activities. }\end{array}$ & $\begin{array}{l}\text { This breakdown in terms of rules and students' } \\
\text { attitudes narrowed Juliana's objective of } \\
\text { supporting students' English learning. } \\
\text { Students did not want to do any academic } \\
\text { tasks; instead, they preferred movie time and } \\
\text { entertainment. }\end{array}$ & $\begin{array}{l}\text { Students listened to content explanations } \\
\text { along with the teacher read materials after } \\
\text { modeling strategies } \\
\text { Juliana explained texts, asked questions, } \\
\text { modeled activities, and used technology to } \\
\text { show real uses of English. }\end{array}$ \\
\hline Rules & $\begin{array}{l}\text { Use of labs and online materials. } \\
\text { She can adapt material from } \\
\text { institutional documents and } \\
\text { suggest materials. Use the } \\
\text { suggested curriculum. }\end{array}$ & $\begin{array}{l}\text { There were not enough technological tools } \\
\text { available to the teacher for every class. } \\
\text { Students wanted play time only during academic } \\
\text { activities }\end{array}$ & $\begin{array}{l}\text { Use of labs and online materials. She can } \\
\text { adapt material from institutional documents } \\
\text { and suggest materials. Use the suggested } \\
\text { curriculum. } \\
\text { Check availability of tools before the class. } \\
\text { Look for plan b. } \\
\text { Motivated students to do academic activities } \\
\text { by integrating their outside digital literacy } \\
\text { practices. }\end{array}$ \\
\hline
\end{tabular}


made her cross boundaries by entering in a territory completely unknown to her in order to transform some elements of her teaching. Indeed, results also revealed how the identified contradictions turned into learning opportunities that enriched her teaching practicum, such as the changes in the AT element object of her class. She understood how the use of technology changes her traditional way of teaching grammar and vocabulary. Furthermore, gains were observed in her planning such as the design of communicative activities as well as in students' motivation towards the new activities that involve technology. Therefore, we aligned with Barab \& Scheckler (2004) that contradictions occurred in the "exchange value of what is learned" and in the "use value of learning when addressing real-world problems" (p. 80). Problems we face in our teaching can turn into learning opportunities and expand our knowledge of the world.

Although theory suggests that crossing boundaries is not immediately seen in the practicum of any individual until he or she is conscious of a need or gap, we could identify from the very beginning of the project how Juliana questioned and analyzed her practicum with a unique motive: generating changes in students' motivation to communicate ideas, read, and write. These results concurred with those obtained by Drucker (2000) and Sagre et al. (2021) in the field of AT. The authors traced the contradictions teachers faced and found that tensions emerge once the practitioner identifies contradictory forces that provoke changes in their way of thinking and in their praxis (Potari, 2013). Results also demonstrate that AT helps teachers recognize individual, social, and contextual factors that shape PSTs' learning and their instructional practices within a class (Yamagata-Lynch, \& Haudenschild, 2009).

As for implications, results of this study suggest that teaching programs should not only concentrate on providing PSTs knowledge of strategic teaching but also on developing their capacity to engage in "expansive learning by confronting disturbances through crossing boundaries" (Tsui \& Law, 2007, p. 1300). Reconceptualization of Juliana's practice demonstrates that it is highly necessary to study the contradictions teachers, particularly PSTs, face when enrolling in new teaching experiences. Also, while in many studies, professional development courses have provided novice teachers with strategies and theory to impact positively in students' language development (Cherner \& Curry, 2019; Maher, 2020; Carroll, 2011; Milton, 2013; Wray \& Medwell, 2000), this research demonstrated that the study of contradictions in theory and practice gaps can highly reshape teachers' conceptualization of their teaching (Engeström, 2001; Potari, 2013). Thus, action research studies should not be seen as remedial strategies applied to provoke immediate changes in PST practicum, but rather as opportunities to understand the difficulties and contradictions of theoretical underpinnings, practical issues, and technical matters (Braga, 2006).

Findings from this study also bring important implications for the role of the advisors in solving contradictions during PSTs' practicum. One of these is that advisors should not only concentrate on how much our students learn new strategies but also how much they have acquired transferable skills for transforming their contexts, contradictions, new educational systems, and pedagogies. In this sense, this study suggests teaching practicum advisors should go beyond product-oriented teaching activities to more process-oriented scenarios and tasks to understand dilemmas, challenges, and contradictions practitioners face when putting theory into practice (Braga, 2006).

Finally, the study suggests that further research may benefit from the analysis of teachers' implementation of students' digital literacy practices to understand how to incorporate these new literacies in their EFL public contexts. In addition, it suggests that it is necessary to analyze the contradictions that may emerge during teachers' 
agency and institutional requirements. This will shed light on possible suggestions for reshaping the institutional principles, curriculum, and policies concerning the teaching of literacy in public sectors (Sannino \& Engeström, 2018). Moreover, further research should concentrate on the analysis of contradictory dynamics that take place when incorporating teachers' self-directed literacy practices in their lessons and tasks and its implications for students' learning. In addition, a more situated practice is needed to understand the shifts we observed between theory and practice in Juliana's teaching process and how she kept shaping her activity system on her own after the project.

\section{References}

Ares, N. M., \& Peercy, M. M. (2003). Constructing literacy: How goals, activity systems, and text shape classroom practice. Journal of Literacy Research, 35(1), 633662. https://doi.org/10.1207/s15548430jlr3501_4

Barab, S, S., \& Scheckler, R. (2004). Using activity theory to conceptualize online community and using online community to conceptualize activity theory. Mind, Culture, and Activity, 11(1), 25-47. https://doi. org/10.1207/s15327884mca1101_3

Barahona, M. (2015). Contradictions in the activity of learning to teach English in Chile. In B. Selau, \& R. Fonseca (Eds.), Cultural historical approach: Educational research in different contexts (pp. 73-97). EDIPUCRS. http://www.pucrs.br/edipucrs

Braga, F. (2006). Using thematic analysis in psychology. Qualitative Research in Psychology, 3(2), 77-101. https://doi.org/10.1191/1478088706qp063oa

Braun, V., \& Clarke, V. (2006). Using thematic analysis in psychology. Qualitative Research in Psychology, 3(2), 77-101. https://doi. org/10.1191/1478088706qp063oa

Bull, G., Thompson, A. D., Schmidt-Crawford, D., Garofalo, J., Hodges, C. B., Spector, J. M., Ferdig, R. E., Edyburn, D. \& Kinshuk. (2016). Evaluating the impact of educational technology. Journal of Digital Learning in Teacher Education, 32(4), 117-118. https://doi.org/10.1080/21532974.2016.1217052

Bullock, S. (2016). Digital technologies in teacher education: From mythologies to making. In C. Kosnik, S. White, C.Beck, B. Marshall,L. Goodwin, \& J.Murray (Eds.), Building bridges: Rethinking literacy teacher education in a digital era (pp. 3-16). Sense Publishers. https://doi.org/10.1007/978-94-6300-491-6_1

Carroll, J. (2011). From encyclopedias to search engines: Technological change and its impact on literacy learning. Literacy Learning in the Middle Years, 19(2), 27-32. https://search.informit.com.au/documentSu mmary; $\mathrm{dn}=111439096519180 ;$ res=IELHSS

Cherner, T. S., \& Curry, K. (2019). Preparing pre-service teachers to teach media literacy: A response to "fake news". Journal of Media Literacy Education, 11(1), 1-31. https://doi.org/10.23860/ JMLE-2019-11-1-1

Coiro, J., Knobel, M., Lankshear, C., \& Leu, D. J. (2008). Central issues in new literacies and new literacies research. In J. Coiro, M. Knobel, C. Lankshear, \& D. J. Leu (Eds.), Handbook of research on new literacies (pp. 1-21). Lawrence Erlbaum Associates.

Colombia, Ministerio de Educación Nacional - MEN-. (2016). Derechos básicos de aprendizaje de inglés: grados transición a $5^{\circ}$ de primaria (Basic learning English rights: Preschoool to $5 t^{h}$ grade). Retrieved from http:// aprende.colombiaaprende.edu.co/sites/default/files/ naspublic/ colombiabilingue/dbacurriculo/cartilla $\mathrm{dba} /$ Derechos\%20Baicos\%20de\%20Aprendizaje-\% 20Tr\%20y\%20Primaria.pdf

Díaz, A. E., \& Rúa, J. A. (2016). Qué hay en los estándares básicos de competencia en lengua extranjera sobre formación cultural? [What is there in the basic foreign language competence standards about cultural education?]. Lenguaje, 44(2), 289-311. https://doi. org/10.25100/lenguaje.v44i2.4624

Drucker, P. (2000). Peter Drucker on the profession of management. Harvard Business School Press.

Duff, P. (2008). Case study research in applied linguistics. Taylor \& Francis. https://doi.org/10.1017/ S0267190514000051

Engeström, Y. (1987). Learning by expanding: An activity theoretical approach to develop-mental research. Orienta-Konsultit Oy. http://lchc.ucsd.edu/mca/ Paper/Engestrom/Learning-by-Expanding.pdf

Engeström, Y. (1999). Activity theory and individual and social transformation. Engeström, R. Miettinen, \& R.-L. Punamäki (Eds.), Perspectives on activity theory (pp. 19-38). Cambridge University. Press. https:// doi.org/10.1017/CBO9780511812774.003

Engeström, Y. (2001). Expansive learning at work: Toward an activity theoretical reconceptualisation. Journal of Education and Work, 14(1), 133-156. https:// doi.org/10.1080/13639080020028747 
Gee, J. P. (1996). Social linguistics and literacies: Ideology in discourses. Falmer.

Hasan, H. \& Kazlauskas, A. (2014). Activity theory: Who is doing what, why and how. [report] Faculty of Business, University of Wollongong, Australia. https:// ro.uow.edu.au/buspapers/403

Lankshear, C., \& Knobel, M. (2011). New literacies: Everyday practices and social learning. Open University Press. https://doi.org/10.1075/pc.18.1.15sew

Maher, D. (2020). Pre-service teachers' digital competencies to support school students' digital literacies. In J. Keengwe, \& G. Onchwari (Eds.), Handbook of research on literacy and digital technology integration in teacher education (pp. 29-46). IGI Global. https:// doi.org/10.4018/978-1-7998-1461-0.ch002

Milton, M. K. (2013). The enlightenment meets twitter: using social media in the social studies classroom. Ohio Social Studies Review, 50(2), 1-29.

Morf, M. E., \& Weber, W. G. (2000). I/O psychology and the bridging potential of A. N. Leont'ev's activity theory. Canadian Psychology, 41(2), 81-93. https:// doi.org/10.1037/h0088234

Nelson, C. (2002). Contradictions in learning to write in a second language classroom: Insights from radical constructivism, activity theory, and complexity theory. [Unpublished doctoral dissertation]. The University of Texas at Austin. UT Electronic Theses and Dissertations. http://hdl.handle.net/2152/812

Nunan, D., \& Bailey, K. M. (2009). Exploring second language classroom research. A comprehensive guide. Heinle.

Park, J. H., \& De Costa, P. (2015). Reframing graduate student writing strategies from an activity theory perspective. Language and Sociocultural Theory, 2(1), 25-50. https://doi.org/10.1558/lst.v2i1.24977

Potari, D. (2013). The relationship of theory and practice in mathematics teacher professional development: an activity theory perspective. ZDM, 45(4), 507-519. https://doi.org/10.1007/s11858-013-0498-2

Roth, W.-M., Tobin, K., Elmesky, R., Carambo, C., McKnight, Y.-M., \& Beers, J. (2004). Re/making identities in the praxis of urban schooling: $A$ cultural historical perspective. Mind, culture, and activity, 11(1), 48-69. https://doi.org/10.1207/ s15327884mca1101_4

Sagre, A., Herazo, R., García, P., Becerra, P., Pacheco, L., \& Gonzalez, L. (2021). Contradictions and critical praxis in foreign language teachers' implementation of Reading-to-Learn. Teaching and Teacher
Education, 108, 03515. https://doi.org/10.1016/j. tate.2021.103516

Said, M. N. H. M., Forret, M., \& Eames, C. (2014). Analysis of contradictions in online collaborative learning using activity theory as analytical framework. Journal Teknologi, 68(2), 57-63. https://doi.org/10.11113/ jt.v68.2910

Said, M. N. H. M., Hassan, J., Idris, A. R., Zahiri, M. A., Forret, M., \& Eames, C. (2013). Technology-enhanced classroom learning community for promoting tertiary ICT education learning in Malaysia. In K. M. Yusof, M. Arsat, M. T. Borhan, E. de Graff, A. Kolmos, \& F. A. Phang (Eds.), PBL across cultures (pp. 326-334). Aalborg University Press. https://doi. org/10.11113/jt.v68.2910

Sannino, A. E., Daniels, H. E., \& Gutiérrez, K. D. (2009). Learning and expanding with activity theory. Cambridge University Press. https://doi. org/10.1017/CBO9780511809989

Sannino, A. \& Engeström, Y. (2018). Cultural-historical activity theory: Founding insights and new challenges, Cultural-Historical Psychology, 14(3), 43-56. https://doi.org/10.17759/chp.2018140305

Smagorinsky, P., Gibson, N., Bickmore, S. T., Moore, C. P., \& Cook, L. S. (2004). Praxis shock: Making the transition from a student-centered university program to the corporate climate of schools. English Education, 36(3), 214-245. https://www.jstor.org/ stable/40173094

Stouraitis, K., Potari, D., \& Skott, J. (2015). Contradictions and shifts in teaching with a new curriculum: The role of mathematics. In CERME 9-Ninth Congress of the European Society for Research in Mathematics Education (pp. 3262-3268). https://hal.archivesouvertes.fr/hal-01289878/document

Tour, E. (2012). TESOL in times of change. Monash University Linguistics Papers. Special Issue, 8(1), 11-21. https:// www.researchgate.net/publication/279022319_ TESOL_in_the_time_of_change

Tsui, A., \& Wong, J. L. N. (2010). In search of a third space: Teacher development in mainland China. In C. Chan, $\&$ N. Rao (Eds.), Revisiting the Chinese learner (vol. 25, pp. 281-311). Springer/The University of Hong Kong, Comparative Education Research Centre. https://doi.org/10.1007/978-90-481-3840-1_10

Tsui, A., \& Law, D. (2007). Learning as boundary-crossing in school-university partnership. Teaching and Teacher Education, 23(8), 1289-1301. https://doi. org/10.1016/j.tate.2006.06.003 
Wray, D., \& Medwell, J. (2000). Professional development for literacy teaching: The evidence from effective teachers. Journal of InService Education, 26(3), 487-498. https://doi. org/10.1080/13674580000200134
Yamagata-Lynch, L. C., \& Haudenschild, M. T. (2009). Using activity systems analysis to identify inner contradictions in teacher professional development. Teaching and Teacher Education, 25(3), 507-517. https://doi.org/10.1016/j.tate.2008.09.014

How to cite this article: García-Montes, P. A., Martínez, J. S., \& Romero, A. (2022). Contradictions in learning to teach digital literacy practices in an EFL public setting: An activity theory analysis. Íkala, Revista de Lenguaje y Cultura, 27(1), 105-124. https://doi.org/10.17533/udea.ikala.v27n 1 a06 